U.S. Department of the Interior
U.S. Geological Survey

\title{
Satellite Image Atlas of Glaciers of the World
}

The world's glaciers react to and interact with changes in global and regional climates. Most mountain glaciers worldwide have been retreating since the latter part of the 19th century; global sea level has risen about 10 centimeters during the past century. Glaciers vary in size as a result of several factors, of which climate variation is probably the most important. The reasons we are interested in glacier variation include its connection to climate change and to global sea level.

The present volume of the Earth's glacier ice, if totally melted, represents 80 meters in sea-level rise. From minimum (an interglacial epoch) to maximum (an ice-age epoch) volume of glacier ice on the continents, sea level has a range of 200 meters. For example, during the last glacial peak, about 20,000 years ago, sea level is estimated to have been 120 meters lower than it is today. During a warmer climatic interval in the last interglacial period, 125,000 years ago, sea level was about 6 meters higher than it is today; during an even warmer interval 3 million years ago, sea level is estimated to have been 25 to 50 meters higher. Sea-level changes, especially in low-lying coastal areas and on islands, have significant effects on human activities and facilities.

A thorough global baseline study of the areal extent of existing glaciers is required if we are going to assess the magnitude of changes in glaciers that will occur worldwide during the next few decades. This research comprises a comprehensive global baseline study of the total area of glacier ice on Earth. The effort is important because present and future changes in glacier margins worldwide cannot be assessed without such a baseline study. The atlas also includes ancillary information from historical and modern ground observations by glaciologists.

One element of the Earth's cryosphere (frozen water) amenable to global inventorying and areal-change monitoring with Landsat images is glaciers. In 1978, the USGS decided to prepare an 11-chapter U.S. Geological Survey Professional Paper, Satellite Image Atlas of Glaciers of the World. In this volume, Landsat 1, 2, and 3 multispectral scanner (MSS) images and Landsat 2 and 3 return beam vidicon (RBV) images are used to inventory the areal occurrence of glacier ice on our planet within the boundaries of the spacecraft's coverage (between about $82^{\circ}$ north and south latitudes). Between 1979 and 1981, optimum Landsat images were distributed to a team of 60 scientists, representing 25 nations and 45 institutions, who agreed to author sections of the Professional Paper concerning either a geographic area or a glaciological topic.

In addition to analyzing images of a specific geographic area, each author summarized up-to-date information about the glaciers within the area and compared their present areal distribution with historical information (from published maps, reports, photographs, and so on) about their past extent. Due to the limitations of Landsat

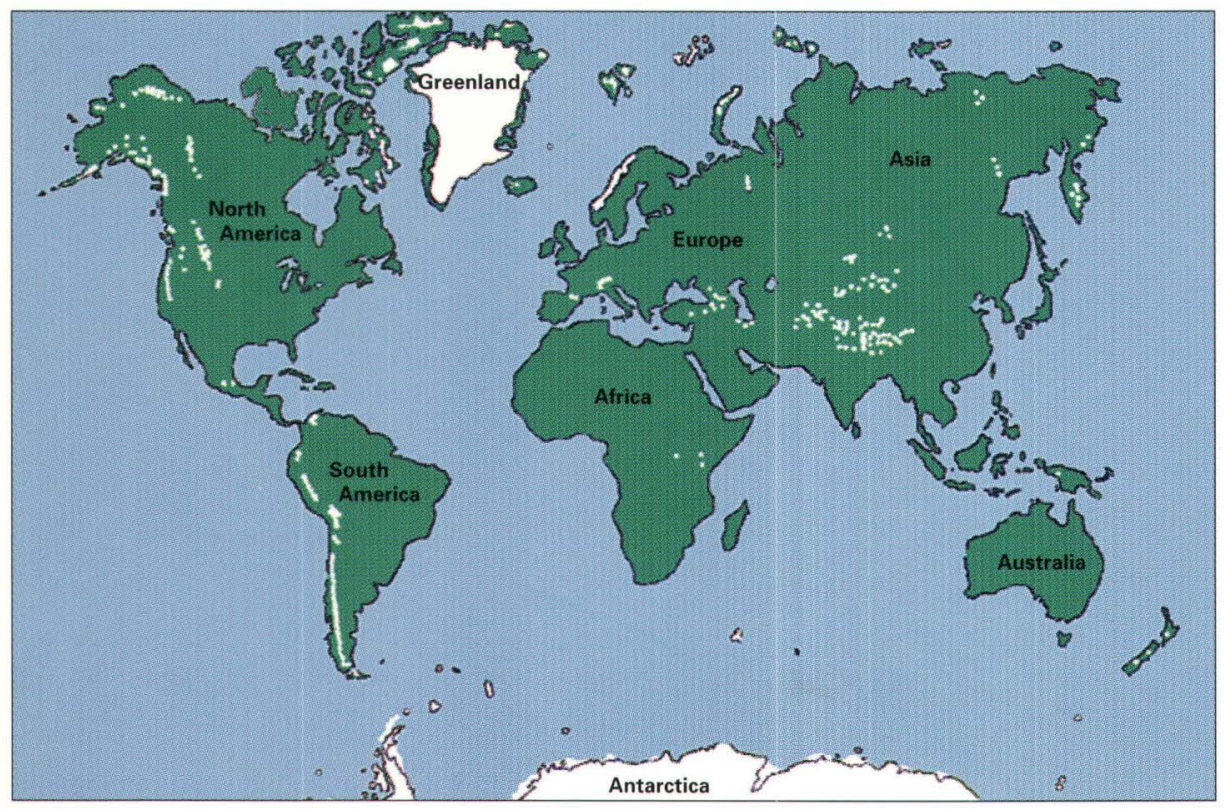

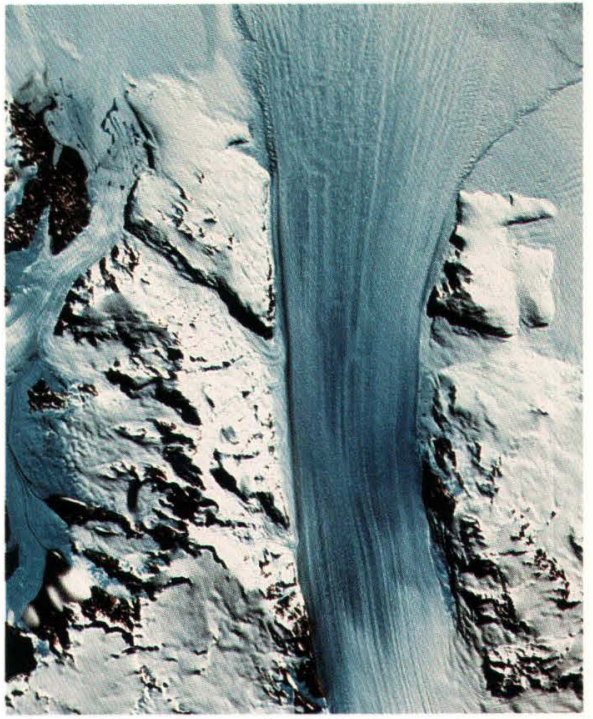

Figure 23 in Chapter B, Antarctica. Landsat 1 MSS image of the Byrd Glacier where it joins the Ross Ice Shelf.

images for delineating or monitoring small glaciers in some geographic areas (the result of inadequate spatial resolution, lack of suitable seasonal coverage, or absence of coverage), information on areal distribution is sometimes necessarily derived from ancillary sources.

Completion of the atlas in the late 1990's will provide an accurate regional inventory of the areal extent of glaciers on our planet during a relatively narrow time interval (1972-1982). This global "snapshot" of glacier extent is already used for comparative analysis with previously published maps and aerial photographs, as well as with new maps, satellite images, and aerial photographs, to determine the areal fluctuation of glaciers in response to natural or human-induced changes in the Earth's climate. For example, sequential Landsat images have documented major changes in the coastal regions of Antarctica.

White areas show giaciers and ice sheets around the world. The white spots in the oceans are islands where glaciers are found. Reproduced from National Geogrāuhic WORLD (February 1977, no. 18, p. 6) with permission. 


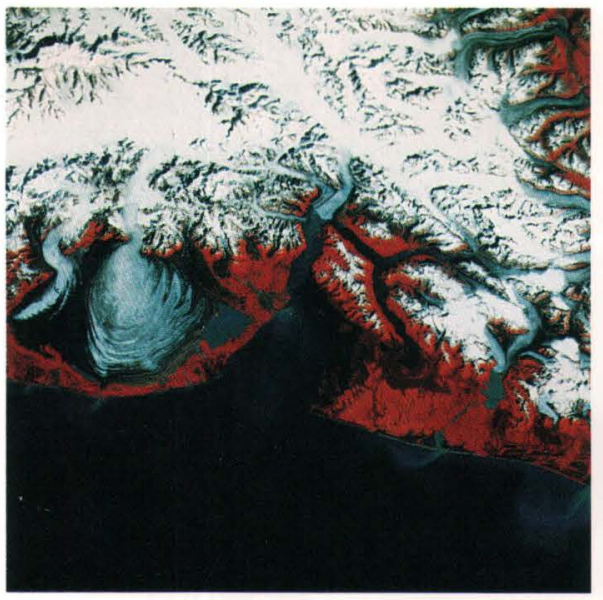

Selected illustrations from the volume. Image from Chapter J, North America. Landsat 2 MSS image of Malaspina Glacier, Alaska.

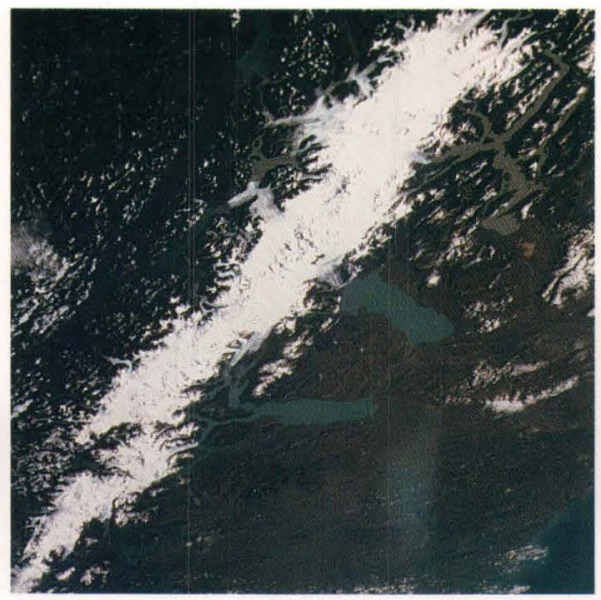

Figure from Chapter I, Glaciers of South America. Salyut- 6 photograph of the Southern Patagonian Ice Field, Chile and Argentina.

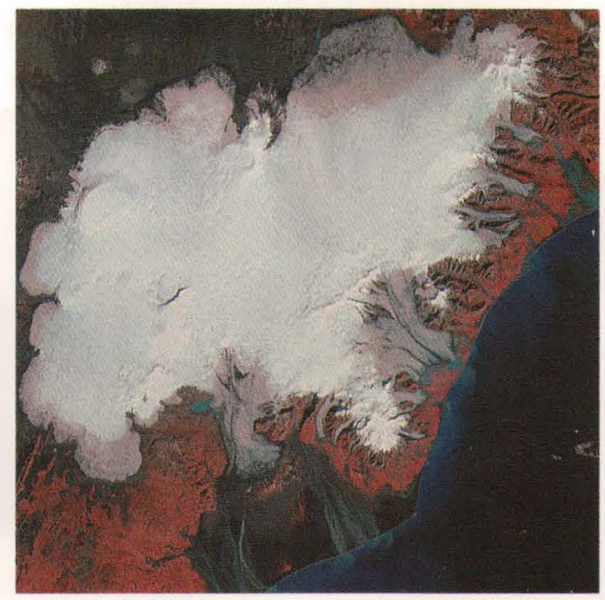

Figure from Chapter D, Glaciers of Iceland. Landsat 1 MSS image of Iceland's largest (8,300 square kilometers) ice cap, Vatnajökull.
Chapter A contains introductory material and several appendices (including a CD-ROM showing all Landsat images listed in the tables for each chapter) and a discussion of the physical characteristics, classification, and global distribution of glaciers. The next nine chapters, B through J, are arranged geographically (see table) and present glaciological information on each of the geographic areas from Landsat and other data sources. The final chapter, $\mathrm{K}$, is a topically oriented chapter that presents related glaciological topics.

\begin{tabular}{clc}
\hline Chapter & \multicolumn{1}{c}{ Region } & $\begin{array}{c}\text { Date } \\
\text { published }\end{array}$ \\
\hline B & Antarctica & 1988 \\
\hline C & Greenland & 1995 \\
\hline D & Iceland \\
\hline E & Continental Europe* & 1993 \\
\hline F & $\begin{array}{l}\text { USSR, China (P.R.C.), } \\
\text { India, Nepal, Afghanistan, } \\
\text { and Pakistan }\end{array}$ \\
\hline G & Turkey, Iran, and Africa \\
\hline H & $\begin{array}{l}\text { Irian Jaya (Indonesia) } \\
\text { and New Zealand }\end{array}$ \\
\hline I & South America \\
\hline J & North America \\
\hline
\end{tabular}

' except for the European part of the Former Soviet Union

For more information, please contact:

Dr. Richard S. Williams, Jr. or

Jane G. Ferrigno

U.S. Geological Survey

Woods Hole, MA 02543

Tel: (508) 457-2347

Fax: (508) 457-2310

Internet: rwilliam@nobska.er.usgs.gov

\section{Foreword to the Volume}

On 23 July 1972, the first Earth Resources Technology Satellite (ERTS 1 or Landsat 1) was successfully placed in orbit. The success of Landsat inaugurated a new era in satisfying mankind's desire to better understand the dynamic world upon which we live. Space-based observations have now become an essential means for monitoring global changes.

The short- or long-term cumulative effects of processes that cause significant changes on the Earth's surface can be documented and studied by repetitive Landsat images. Such images provide a permanent historical record of the surface of our planet; they also make possible comparative two-dimensional measurement of change over time. Professional Paper 1386 demonstrates the importance of the application of Landsat images to global studies by using them to determine the current distribution of glaciers on our planet. As images become available from future satellites, the new data will be used to document global changes in glacier extent by reference to the image record of the 1970's.

Although many geological processes take centuries or even millennia to produce obvious changes on the Earth's surface, other geological phenomena, such as glaciers and volcanoes, cause noticeable changes over shorter periods. Some of these phenomena have worldwide impact and often are interrelated. Explosive volcanic eruptions can produce dramatic effects on the global climate. Natural or culturally induced processes can cause global climatic cooling or warming. Glaciers respond to such warming or cooling periods by decreasing or increasing in size, thereby causing sea level to rise or fall.

As our understanding of the interrelationship of global processes improves and our ability to assess changes caused by these processes develops further, we will learn how to use indicators of global change, such as glacier variation, to more wisely manage the use of our finite land and water resources. Professional Paper 1386 is an excellent example of the way in which we can use technology to provide needed earth-science information about our planet. The international collaboration represented by this report is also an excellent model for the kind of cooperation that scientists will increasingly find necessary in the future in order to solve important earth-science problems on a global basis. 
SCHEDULE FOR COMPLETION OF THE REMAINING SIX VOLUMES (CHAPTERS) OF THE

SATELLITE IMAGE ATLAS OF GLACIERS OF THE WORLD (U.S. GEOLOGICAL SURVEY PROFESSIONAL PAPER 1386)

\begin{tabular}{|c|c|c|c|c|c|c|c|c|c|}
\hline Chapter & Title & $\begin{array}{l}\text { Completion } \\
\text { of Text and } \\
\text { Illustrations }\end{array}$ & $\begin{array}{c}\text { Completion } \\
\text { of } \\
\text { Preliminary } \\
\text { Review and } \\
\text { Editing } \\
\end{array}$ & $\begin{array}{l}\text { Completion } \\
\text { of Update } \\
\text { by Authors }\end{array}$ & $\begin{array}{l}\text { Completion of } \\
\text { Final Editing }\end{array}$ & $\begin{array}{l}\text { Completion } \\
\text { of } \\
\text { Technical } \\
\text { Reviews }\end{array}$ & $\begin{array}{l}\text { Preparation } \\
\text { of Text and } \\
\text { Illustrations }\end{array}$ & $\begin{array}{c}\text { Page-Proof } \\
\text { Review by } \\
\text { Editors/Authors }\end{array}$ & $\begin{array}{l}\text { Printing } \\
\text { Date }\end{array}$ \\
\hline I & $\begin{array}{l}\text { Glaciers of } \\
\text { South America }\end{array}$ & - & - & - & $31 \mathrm{Jul} 95$ & Sep 95 & $\begin{array}{l}\text { Oct } 95- \\
\text { Mar } 96\end{array}$ & Apr 96 & Jun 96 \\
\hline $\mathbf{J}$ & $\begin{array}{l}\text { Glaciers of } \\
\text { North } \\
\text { America }\end{array}$ & $\begin{array}{l}1 \text { Sep } 95 \\
\text { (Alaska) } \\
1 \text { Oct } 95 \\
\text { (Ellesmere } \\
\text { Island Ice } \\
\text { Shelves) }\end{array}$ & $30 \mathrm{Sep} 95$ & $\begin{array}{l}1 \text { Oct- } \\
30 \text { Nov } 95\end{array}$ & 31 Jan 96 & Mar 96 & $\begin{array}{l}\text { Apr 96- } \\
\text { Sep } 96\end{array}$ & Oct 96 & Dec 96 \\
\hline $\mathrm{D}$ & $\begin{array}{l}\text { Glaciers of } \\
\text { Iceland }\end{array}$ & $\begin{array}{l}1 \text { Jan - } \\
30 \text { Jun } 96\end{array}$ & - & - & 31 Jul 96 & Sep 96 & $\begin{array}{l}\text { Oct } 96- \\
\text { Mar } 97\end{array}$ & Apr 97 & Jun 97 \\
\hline $\mathrm{F}$ & $\begin{array}{l}\text { Glaciers of } \\
\text { Asia }\end{array}$ & - & 30 Sep 96 & $\begin{array}{l}1 \text { Oct } 96- \\
30 \text { Dec } 96\end{array}$ & 31 Jan 97 & Mar 97 & $\begin{array}{l}\text { Apr } 97- \\
\text { Sep } 97\end{array}$ & Oct 97 & Dec 97 \\
\hline K & $\begin{array}{l}\text { Monitoring } \\
\text { and } \\
\text { Understanding } \\
\text { Past \& Present } \\
\text { Changes in the } \\
\text { Cryosphere }\end{array}$ & $\begin{array}{l}1 \text { Jul - } \\
30 \text { Nov } 96\end{array}$ & 30 Apr 97 & $\begin{array}{l}1 \text { May - } \\
30 \text { Jun } 97\end{array}$ & $31 \mathrm{Jul} 97$ & Sep 97 & $\begin{array}{l}\text { Oct } 97- \\
\text { Mar } 98\end{array}$ & Apr 98 & Jun 98 \\
\hline A & $\begin{array}{l}\text { Introduction } \\
\text { and CD-ROM }\end{array}$ & $\begin{array}{l}1 \text { Sep } 97- \\
30 \text { Dec } 97\end{array}$ & - & - & $31 \operatorname{Jan} 98$ & Mar 98 & $\begin{array}{l}\text { Apr } 98 \text { - } \\
\text { Sep } 98 \\
\end{array}$ & Oct 98 & Dec 98 \\
\hline
\end{tabular}

\section{CHAPTERS PUBLISHED TO DATE:}

\section{Chapter Title}

B Antarctica

H Glaciers of Irian Jaya, Indonesia, and New Zealand

G Glaciers of the Middle East and Africa

E Glaciers of Europe

C Greenland

Richard S. Williams, Jr., Jane G. Ferrigno, Editors, 7 July 1995
Year of Publication

1988 (Reprinted in 1994)

1989

1991

1993

1995

Order from:

\begin{tabular}{cc} 
Pages & Price (U.S. $\$$ ) \\
\hline 278 & 28 \\
48 & 4.50 \\
70 & 5 \\
164 & 17 \\
142 & 16
\end{tabular}

USGS Information Service.S Denver Federal Center, Box 25286 Denver, CO 80225, USA 
PRIORITIZATION FOR COMPLETION OF PRODUCTS FROM THE:

\section{SATELLITE IMAGE ATLAS OF GLACIERS OF THE WORLD PROJECT (U.S. Geological Survey Professional Paper 1386)}

1. Schubert, C., _ _ Glaciers of Venezuela (I-1); Hoyos-Patiño, F., __, Glaciers of Colombia (I-2); Jordan, E., and Hastenrath, S., Glaciers of Ecuador (I-3); Morales-Arnao, B., ___ , Glaciers of Peru (I-4), with a section on Quelccaya Ice Cap, by Hastenrath, S.; Jordan, E., __ Glaciers of Bolivia (I-5); and Lliboutry, L., _ Glaciers of Chile and Argentina (I-6), with a section on Rock Glaciers and Glaciers of Argentina by Corte, A.E.; in Williams, R.S., Jr., and Ferrigno, J.G., editors, Satellite image atlas of glaciers of the world: U.S. Geological Survey Professional Paper 1386-I (Glaciers of South America).

2. Ommanney, C.S.L., _ _ Introduction; Andrews, J.T., Koerner, R.M., and Holdsworth, G. (Arctic Islands); Ommanney, C.S.L. (Rocky Mountains); Clarke, G.K.C., and Holdsworth, G. (Coast and St. Elias Mountains); and Jeffries, M.O. (Ice Shelves of Ellesmere Island), , Glaciers of Canada (J-1); Krimmel, R.M., and Molnia, B.F., , Glaciers of Alaska (J-2); Krimmel, R.M., and Meier, M.F., , Glaciers of the Western U.S. (J-3); and White, S.E., , Glaciers of Mexico (J-4); in Williams, R.S., Jr., and Ferrigno, J.G., editors, Satellite image atlas of glaciers of the world: U.S. Geological Survey Professional Paper 1386-J (Glaciers of North America).

3. Williams, R.S., Jr., and Sigurosson, Oddur, , Glaciers of Iceland; with sections on radio-echosounding of Iceland's glaciers by Björnsson, Helgi and Holocene fluctuation of Iceland's glaciers by Guðmundsson, H.J.; in Williams, R.S., Jr., and Ferrigno, J.G., editors, Satellite image atlas of glaciers of the world: U.S. Geological Survey Professional Paper 1386-D.

4. Kotlyakov, V.M., and Vinogradov, V.N., (F-1); Shi, Yafeng, and Krimmel, R.M., , Glaciers of the Former Soviet Union C.P., , Glaciers of India (F-3); Shroder, J.E., Jr., , Glaciers of China (F-2); Vohra, Afghanistan (F-4); Higuchi, Keiji, and Shroder, J.E., Jr., , Glaciers of (F-5); and Krimmel, R.M., , Glaciers of Bhutan (F-6); in Williams, R.S., Jr., and Ferrigno, J.G., editors, Satellite image atlas of glaciers of the world: U.S. Geological Survey Professional Paper 1386-F (Glaciers of Asia). 
5. Clarke, G.K.C., , Surging glaciers (K-1-1); Williams, R.S., Jr., , Jökulhlaups

(K-1-2); Orheim, Olav, , Icebergs (K-1-3); Haeberli, Wilfried, Ice avalanches (K-1-4); and Magnússon, M.M., ; and Snow avalanches (K-1-5); Glaciological Hazards (K-1); Williams, R.S., Jr., and Meier, M.F., and sea level (K-2-1); Haeberli, Wilfried, Glacier Inventories (K-2-2); Haeberli, Wilfried, , Glacier fluctuations (K-2-3); Thompson, L., and Thompson, E.M., , Ice cores, with section on the National Ice Core Facility (U.S.) by Fitzpatrick, J.J. (K-2-4); Østrem, Gunnar, H.J., and Ohmura, A., , Glacier mass balance $(\mathrm{K}-2-5)$; and Gilgen, Climate (K-2); Rapley, C., , Glacier-climate relationship (K-2-6); Glaciers and Williams, R.S., Jr., , Radar altimetry (K-3-1); Garvin, J.B., and Topographic mapping (K-3-3); Dowdeswell, J.H., -4); and Ferrigno, J.G., and Williams, R.S., Jr., , Laser altimetry (K-3-2); Haakensen, Nils, (K-3-5); Glacier Area, Topography, and Thickness (K-3); Gloersen, Per, Barnes, J.C., McClain, E.P., and Campbell, W.J., Matson, M., Snow cover (K-4-2); Svensson, Harald, , Radio-echosounding (K-3 pheonomena $(\overline{\mathrm{K}-4-3})$; Haeberli, Wilfried, , Sea ice (K-4-1); Hall, D.K., and D.K., , Lake ice (K-4-5); Related Topics (K-4); in Williams, R.S., Jr., and Ferrigno, J.G., editors, Satellite image atlas of glaciers of the world: U.S. Geological Survey Professional Paper 1386-K, (Monitoring and Understanding Past and Present Changes in the Cryosphere).

6. Williams, R.S., Jr., and Ferrigno, J.G., , Introduction (including CD-ROM); in Williams, R.S., Jr., and Ferrigno, J.G., editors, Satellite image atlas of glaciers of the world: U.S. Geological Survey Professional Paper 1386-A.

Richard S. Williams, Jr. U.S. Geological Survey Woods Hole, MA 02543 30 June 1995
Jane G. Ferrigno U.S. Geological Survey

Reston, VA 22092

30 June 1995 